\title{
Penilaian Pelajar SMP Di Kota Yogyakarta Terhadap Pictorial Health Warning (PHW)
}

\author{
Citra Denali *), Zahroh Shaluhiyah **), Kusyogo Cahyo***) \\ *) Alumni Magister Promosi Kesehatan \\ Korespondensi citradenali@gmail.com \\ **) Magister Promosi Kesehatan Universitas Diponegoro Semarang \\ ***) Fakultas Kesehatan Masyarakat Universitas Diponegoro
}

\begin{abstract}
ABSTRAK
Berdasarkan data proporsi penduduk umur $\geq 10$ tahun menurut kebiasaan merokok, maka Yogyakarta menempati urutan ke-14, dengan jumlah perokok aktif setiap hari sebanyak 21,2\%. Tujuan penelitian untuk menganalisis faktor yang mempengaruhi penilaian pelajar SMP di Kota Yogyakarta terhadap PHW.

Penelitian ini menggunakan pendekatan kuantitatif yang didukung dengan pendekatan kualitatif. Pendekatan secara kuantitatif dilakukan dengan metode cross sectional dan kualitatif dengan desain metode pendekatan case study. Sampel penelitian merupakan pelajar SMP kelas VII di Kota Yogyakarta, sejumlah 403 pelajar. Informan indepth interview sebanyak 2 orang guru SMP, dan 10 pelajar SMP kelas VII di Kota Yogyakarta.

Hasil penelitian menunjukkan faktor yang berpengaruh terhadap penilaian pelajar SMP di Kota Yogyakarta terhadap PHW adalah keterpaparan PHW, dimana $\rho$ value 0,0001 ( $\rho<$ $0,05)$ dengan OR/Exp (B) 16,610; pengetahuan tentang rokok, dimana $\rho$ value 0,024 ( $\rho<$ $0,05)$ dengan OR/Exp (B) 2,041; dan umur, dimana $\rho$ value 0,029 $(\rho<0,05)$ dengan OR/Exp (B) 1,808. Hasil indepth interview, antara lain bahwa PHW belum mampu membuat seorang perokok aktif (khususnya perokok aktif di kalangan pelajar SMP) untuk memiliki penilaian tentang PHW yang merujuk kepada niatnya dalam berhenti merokok.
\end{abstract}

Kata Kunci : PHW,Penilaian, Pelajar SMP, Rokok

\section{ABSTRACT}

Based on a national data of proportion of domestics aged $\geq 10$ year old related to their smoking behaviour, Yogyakarta is $14^{\text {th }}$ province with highest number of active smokers with a rate of $21,2 \%$ every day.

The purpose of this research is to analyze factors influencing students of junior high schools (SMP) in Yogyakarta regarding their assessment of PHW.

This research is a quantitative researh supported by qualitative data. The quantitative data were obtained by a cross sectional method, while the qualitative ones by case study approach. The samples were 403students who are in seventh grade at several SMPs in Yogyakarta.Informant of indepth interview were 2 teachers SMPs, and 10 students who are in seventh grade at several SMPs in Yogyakarta.

The results of this research show us that 49,1\% of respondens have a negative assessment of PHW. The factors contributing to the assessment of SMP students in Yogyakarta were: exposure of PHW, with $\rho$ value of 0,0001 $(\rho<0,05)$ and OR/Exp $(B)$ of 16,610; knowledge of smoking with $\rho$ value of $0,024(\rho<0,05)$ and $O R / \operatorname{Exp}(B)$ of 2,041 ; and age, with $\rho$ value of 0,029 $(\rho<0,05)$ and $O R / \operatorname{Exp}(B)$ of 1,808. Indepth interview shows that PHW has not been able to make a smoker (SMP student) have assessment of PHW related to them intention to quit smoking.

Key Words : :PHW, Assessment, Junior High School Students, Cigarette 


\section{PENDAHULUAN}

Merokok masih menjadi masalah dunia, termasuk di Indonesia. Indonesia menempati urutan ketiga di dunia dengan jumlah perokok terbanyak setelah China dan India. Tahun 2013, proporsi terbanyak perokok aktif setiap hari pada umur 30-34 tahun sebesar 33,4\% (Badan Penelitian dan Pengembangan Kesehatan, 2013). Data dan penelitian mengenai rokok menyebutkan bahwa konsumsi rokok membunuh satu orang setiap 10 detik (Kemenkes, 2013).

Kesadaran masyarakat akan dampak buruk merokok umumnya rendah. Sebagian besar perokok tidak dapat melihat hubungan antara merokok dan dampak kesehatan. Salah satu penyebabnya adalah tenggang waktu sekitar 20-25 tahun yang dibutuhkan sejak seseorang mulai merokok sampai timbulnya berbagai penyakit akibat rokok. Pemahaman ini membutuhkan informasi yang akurat (WHO, 2009). Pemberitahuan informasi kesehatan rokok ini bisa melalui bungkus atau kemasan rokok.

Awalnya bungkus rokok hanya diberi label peringatan berbentuk tulisan, seperti "Rokok dapat menyebabkan kanker, serangan jantung, impotensi, gangguan kehamilan dan janin." Namun menurut beberapa penelitian mengenai pelabelan peringatan pada bungkus rokok tersebut adalah kurang efektif dalam menyebarkan informasi dampak akibat rokok dan tidak menimbulkan rasa ngeri khususnya untuk para perokok, sehingga tidak mampu mengurangi angka perilaku merokok di Indonesia.

24 Juni 2014 merupakan penerapan peringatan kesehatan berbentuk gambar (Pictorial Health Warning (PHW)) pada bungkus rokok ini diterapkan di Indonesia. Hal ini sesuai dengan PP No 109 tahun 2012 tentang Pengamanan Bahan yang Mengandung Zat Adiktif berupa Produk Tembakau bagi Kesehatan. Pasal 15 menerangkan bahwa "Setiap 1 (satu) varian Produk Tembakau wajib dicantumkan gambar dan tulisan peringatan kesehatan yang terdiri atas 5 (lima) jenis yang berbeda, dengan porsi masing-masing $20 \%$ (dua puluh persen) dari jumlah setiap varian Produk Tembakaunya" (Pemerintah RI, 2012). Lima jenis gambar yang diberlakukan di Indonesia adalah gambar "Merokok sebabkan Kanker Mulut", gambar "Merokok Membunuhmu", gambar "Merokok Sebabkan Kanker Tenggorokan", gambar "Merokok Dekat Anak Berbahaya bagi Mereka", dan gambar "Merokok sebabkan Kanker Paru-Paru dan Bronkitis Kronis.

Data statistik menunjukkan bahwa perokok remaja saat ini berkisar diangka 3,5 juta yang berarti $>15 \%$ jumlah remaja saat ini. Kebanyakan perokok dan pengguna tembakau dewasa mulai melakukan kebiasaan tersebut sebelum mereka dewasa. 
Diantara para remaja yang merokok tersebut, hampir 25\% merokok pertama kali sebelum berusia 10 tahun (Sentra Informasi Keracunan Nasional, 2014). Berdasarkan data proporsi penduduk umur lebih dari sama dengan 10 tahun menurut kebiasaan merokok dan provinsi, maka Yogyakarta menempati urutan ke-14, dengan jumlah perokok aktif setiap hari sebanyak $21,2 \%$. Yogyakarta menyumbang perilaku menghisap rokok sebanyak 10 batang perhari (Badan Penelitian dan Pengembangan Kesehatan, 2013).

Tinjauan pustaka dalam penelitian ini terdiri dari bahaya rokok pada tubuh, rokok, pictorial health warning (PHW) di Indonesia, remaja, dan faktor-faktor yang mempengaruhi penilaian terhadap Pictorial Health Warning (PHW).

\section{METODOLOGI PENELITIAN}

Metode penelilian yang digunakan dalam penelitian ini adalah pendekatan kuantitatif (metode cross sectional) yang didukung dengan pendekatan kualitatif (metode pendekatan case study). Sampel penelitian merupakan pelajar SMP kelas VII di Kota Yogyakarta, sejumlah 403 pelajar. Informan indepth interview sebanyak 2 orang guru SMP, dan 10 pelajar SMP kelas VII di Kota Yogyakarta. Instrumen yang digunakan dalam penelitian kuantitatif adalah kuesioner. Metode yang digunakan adalah angket. Sedangkan instrumen dalam penelitian kualitatif ini menggunakan instrumen utama dari penelitian yaitu sebagai human instrument dalam pengumpulan data.

\section{HASIL DAN PEMBAHASAN}

\section{Penilaian Pelajar SMP di Kota}

\section{Yogyakarta tentang PHW}

Hasil analisis univariat menunjukkan responden yang memiliki penilaian negatif terhadap PHW sebesar 49,1\%. Penilaian negatif terhadap PHW memiliki arti tidak menimbulkan rasa ngeri, tidak serem, tidak takut, tidak jijik, dan berpikir bahwa perokok aktif tidak akan terkena hal yang ada pada gambar peringatan, serta memiliki penilaian bahwa karakteristik media yang kurang baik. Variabel Penilaian terhadap PHW merupakan penjumlahan dari subvariabel isi pesan PHW dengan tampilan PHW.

Tabel 1. Komposit Isi Pesan PHW dan Tampilan PHW

\begin{tabular}{clccc}
\hline \multicolumn{1}{c}{ Pertanyaan } & $\begin{array}{c}\text { Tidak } \\
\text { Memilih*) }\end{array}$ & $\begin{array}{c}\text { Memilih } \\
\text { Sebagian } \\
\text { PHW**) }\end{array}$ & $\begin{array}{c}\text { Memilih 5 } \\
\text { Jenis } \\
\text { PHW***) }\end{array}$ \\
\hline Isi Pesan PHW & & & \\
1 & PHW membuat rasa ngeri, serem, dan takut & $21.6 \%$ & $40.7 \%$ & $37.7 \%$ \\
2 & PHW membuat rasa jijik & $12.9 \%$ & $68.2 \%$ & $18.9 \%$ \\
3 & Perokok aktif akan terkena hal yang ada pada gambar & $49.1 \%$ & $36.8 \%$ & $14.1 \%$ \\
\hline
\end{tabular}


Lanjutan Tabel 1

\begin{tabular}{|c|c|c|c|c|}
\hline \multicolumn{5}{|c|}{ Tampilan PHW } \\
\hline 1 & Desain penyajian gambar PHW ini menarik & $48.6 \%$ & $43.5 \%$ & $7.9 \%$ \\
\hline 2 & Gambar PHW ini jelas dari sisi warna dan bentuk & $3.5 \%$ & $35.5 \%$ & $61.0 \%$ \\
\hline 3 & $\begin{array}{l}\text { Kualitas warna pada gambar PHW ini memiliki } \\
\text { perpaduan yang baik, sehingga bisa dilihat kontras } \\
\text { warna dan tepiannya }\end{array}$ & $15.1 \%$ & $37.8 \%$ & $47.1 \%$ \\
\hline 4 & $\begin{array}{l}\text { Jika gambar ini ada di iklan } \mathbf{T V} \text {, maka tulisan } \\
\text { keterangan gambar ini terlihat dan terbaca }\end{array}$ & $12.7 \%$ & $57.5 \%$ & $29.8 \%$ \\
\hline 5 & $\begin{array}{l}\text { Jika gambar ini ada di baliho pinggir jalan, maka } \\
\text { tulisan keterangan gambar ini terlihat dan terbaca }\end{array}$ & $34 \%$ & $50.9 \%$ & $15.1 \%$ \\
\hline 6 & $\begin{array}{l}\text { Jika gambar ini ada di bungkus rokok, maka tulisan } \\
\text { keterangan gambar ini terlihat dan terbaca }\end{array}$ & $15.1 \%$ & $44.5 \%$ & $40.4 \%$ \\
\hline
\end{tabular}

Keterangan:

*) Tidak memilih, artinya adalah responden tidak memilih kelima jenis PHW.

**) Memilih sebagian PHW, artinya adalah responden memilih salah satu atau lebih dari kelima jenis PHW tetapi tidak memilih semua PHW (memilih 1 sampai dengan 4 jenis PHW), contohnya responden memilih gambar 3 dan 5 saja, atau hanya memilih gambar 1 .

***) Memilih 5 jenis PHW, artinya adalah responden memilih seluruh PHW (kelima gambar).

Tabel diatas menunjukkan data dari sub variabel isi pesan PHW ini menunjukkan bahwa sebanyak $37,7 \%$ responden menyatakan bahwa kelima jenis PHW tersebut menimbulkan rasa ngeri, serem, dan takut. Gambar yang paling banyak mendapatkan pilihan "ngeri, serem, dan takut" (sebanyak 273 responden) adalah gambar 5 (Merokok sebabkan Kanker Paru-Paru dan Bronkitis Kronis). Sebanyak $18,9 \%$ responden menyatakan bahwa kelima jenis PHW tersebut menimbulkan rasa jijik. Gambar yang paling banyak mendapatkan pilihan "jijik" (sebanyak 294 responden) adalah gambar 5 (Merokok sebabkan Kanker Paru-Paru dan Bronkitis Kronis). Sebanyak 14,1\% responden menyatakan bahwa perokok aktif akan terkena hal yang ada pada gambar. Gambar yang paling banyak mendapatkan pilihan "perokok aktif akan terkena hal yang ada pada gambar" (sebanyak 143 responden) adalah gambar 1 (Merokok sebabkan Kanker Mulut). Data dari sub variabel tampilan PHW ini menunjukkan bahwa sebanyak $7,9 \%$ responden menyatakan bahwa desain penyajian gambar kelima jenis PHW menarik. Sebanyak $61,0 \%$ responden menyatakan bahwa kelima jenis PHW ini jelas dari sisi warna dan bentuk. Sebanyak 40,4\% responden menyatakan bahwa jika kelima jenis PHW ini ada di bungkus rokok, maka tulisan keterangan gambar ini terlihat dan terbaca.

Data indepth interview menyimpulkan bahwa hampir semua informan menyatakan bahwa PHW membuat atau menimbulkan rasa ngeri, serem, takut, jijik, dan berpikir jika perokok aktif akan terkena hal yang ada pada gambar. Alasan menimbulkan rasa ngeri/serem/takut adalah informan membayangkan kondisi kecacadan penderita yang ada pada gambar, dan 
membayangkan jika penyakit itu terjadi padanya atau kepada orang terdekatnya. Alasan menimbulkan rasa jijik antara lain karena bentuk dan warna dari gambar penyakit akibat merokok tersebut (hal ini menerangkan gambar 1,3, dan 5). Dan untuk gambar 2 dan 4, ini juga menimbulkan rasa ngeri/serem/takut dan jijik, karena terdapat gambar tengkorak, dan perilaku dari "sang ayah" yang merokok sambil menggendong anaknya.

Penilaian pelajar SMP kelas VII di Kota Yogyakarta terhadap PHW ini dihubungkan dengan pendapat pelajar mengenai niat berhenti merokok. Kesimpulan hasil indepth interview adalah seluruh informan menyatakan bahwa PHW bisa membuat seseorang yang belum merokok untuk berniat tidak merokok. PHW juga mampu membuat mantan perokok untuk berniat berhenti merokok atau tidak mau melanjutkan perilaku merokoknya setelah melihat PHW tersebut, khususnya untuk gambar 1 (Merokok sebabkan Kanker Mulut), 3 (Merokok Sebabkan Kanker Tenggorokan), dan 5 (Merokok sebabkan Kanker Paru-Paru dan Bronkitis Kronis). Namun PHW tidak membuat seorang perokok aktif untuk berhenti merokok.

Rokok memiliki kekuatan adiksi yang terbilang besar. Orang yang terlanjur memiliki kebiasaan merokok, sulit untuk menghentikannya. Menghentikan perilaku merokok bukanlah usaha mudah, terlebih lagi bagi perokok di Indonesia (Fawzani, N., dan Triratnawati, 2005). Kondisi kecanduan inilah yang membuat para perokok, khususnya para remaja atau pelajar SMP yang merokok ini merasa atau beranggapan bahwa peringatan (PHW) yang sudah dicanangkan oleh pemerintah tidak membuat mereka takut, ngeri, seram, jijik, dan tidak setuju jika hal-hal mengerikan yang ada pada gambar akan terkena pada para perokok. Hal lain yang membuat mereka merasa PHW tidak memiliki arti besar adalah karena mereka beranggapan mereka masih muda dan mereka merokok dengan skala kecil ke sedang. Maksudnya adalah mereka berpikir jika orang yang merokok banyak atau skala besarlah yang akan sakit nantinya.

\section{Umur Pelajar SMP kelas VII}

Umur menunjukkan kemaknaan, dimana $\rho$ value $0,029(\rho<0,05)$ dengan OR/Exp (B) 1,808. Hal ini berarti bahwa umur remaja yang lebih dari 13 tahun mempunyai peluang 2 kali lebih besar mendukung terjadinya penilaian positif PHW dibandingkan remaja yang berumur kurang dari 13 tahun. Hasil penelitian ini adalah sebanyak $74,7 \%$ responden masuk ke dalam kategori remaja dewasa. Hasil uji statistik diperoleh nilai $\rho$ sebesar 0,005 , artinya ada hubungan antara umur dengan 
penilaian pelajar SMP di Kota Yogyakarta terhadap PHW.

Menurut CDC dalam Sheaves (2008), di Virginia terdapat sekitar 4.000 orang antara usia 12 sampai 17 yang memulai merokok. Menurut Rachmat, Thaha, dan Syafar (2013), Indonesia mengalami peningkatan terbesar perilaku merokok yang cenderung dimulai pada usia yang semakin muda, yaitu pada usia 10-14 tahun.

Umur ini berkaitan dengan rokok, karena tidak ada aturan larangan tentang batasan atau kelompok umur yang diperbolehkan untuk membeli rokok dan atau berperilaku merokok.

\section{Karakteristik Orang Tua (Pendidikan dan Pendapatan)}

Berdasarkan hasil penelitian diketahui bahwa, sebanyak $75,9 \%$ responden memiliki ayah yang berpendidikan lanjutan (lebih dari SMP), 73,9\% responden memiliki ibu yang berpendidikan lanjutan (lebih dari SMP), dan 52,1\% responden yang yang orangtuanya memiliki pendapatan tinggi. Hasil uji statistik diperoleh nilai $\rho$ sebesar 0,151 untuk pendidikan ayah, nilai $\rho$ sebesar 0,635 untuk pendidikan ibu, dan nilai $\rho$ sebesar 0,643 untuk pendapatan orang tua, artinya ada tidak hubungan antara pendidikan ayah, pendidikan ibu, dan pendapatan orang tua dengan penilaian pelajar SMP di Kota Yogyakarta terhadap PHW.
Menurut Edoka (2013), perokok jangka panjang atau bisa dikatakan seseorang yang merokok dari usia dini ini lebih terfokus pada seseorang dengan latarbelakang sosial ekonomi rendah. Menurut penelitian Khuloud, bahwa siswa (pelajar SMP) dari status sosial-ekonomi yang rendah, berada pada risiko yang lebih tinggi untuk berperilaku merokok dari siswa dari status sosial-ekonomi yang tinggi (2007). Bahwasanya dalam penelitian ini, selisih jumlah diantara pendapatan orang tua yang rendah dan tinggi adalah 4,2\%. Selisih ini tidaklah terlampau jauh. Maka hal ini menjadi alasan untuk pendapatan orang tua tidak memuliki hubungan dengan penilaian pelajar SMP terhadap PHW.

\section{Keterpaparan PHW}

Keterpaparan PHW menunjukkan kemaknaan, dimana $\rho$ value 0,0001 ( $\rho<$ 0,05) dengan OR/Exp (B) 16,610. Hal ini berarti bahwa seseorang yang terpapar 5 jenis PHW ini mempunyai peluang 17 kali lebih besar mendukung terjadinya penilaian positif PHW dibandingkan yang tidak terpapar 5 jenis PHW.

Hal ini sesuai dengan pendapat Blow, Leicester, dan Windmeijer (2005), yaitu kemudahan akses ke rokok, baik dari pengecer atau anggota keluarga merupakan salah satu faktor perilaku merokok. Hal ini menjelaskan bahwa akses untuk memiliki rokok dari pengecer atau penjual, dan iklan 
rokok yang memunculkan keterpaparan PHW. Menurut Appau (2011), ketersediaan produk tembakau untuk para remaja ini dapat menjadi faktor yang berkontribusi terhadap inisiasi merokok atau faktor untuk mencoba merokok.

Keterpaparan PHW dalam penelitian ini berhubungan dengan penilaian pelajar SMP terhadap PHW. Hasil penelitian ini menyatakan bahwa lebih dari setengah jumlah responden terpapar 5 jenis PHW $(72,0 \%)$. Hal ini menunjukkan bahwa responden pernah melihat gambar peringatan yang ada di bungkus rokok (PHW). Dari hasil penelitian juga diketahui bahwa responden pernah melihat PHW tersebut pada bungkus rokok yang ada di toko kelontong, penjual keliling, supermarket, rumah, dan tempat kumpul.

\section{Ketersediaan Kegiatan Kesehatan di Sekolah}

Hasil penelitian ini menyatakan sebanyak $85,4 \%$ ketersediaan kegiatan kesehatan di sekolahnya cukup lengkap. Berdasarkan hasil uji statistik diperoleh nilai $\rho$ sebesar 0,675 , artinya ada tidak hubungan antara ketersediaan kegiatan kesehatan di sekolah dengan penilaian pelajar SMP di Kota Yogyakarta terhadap PHW.

Menurut CDC (2004), pemasaran informasi bisa dengan motode presentasi atau penyuluhan yaitu saat presentasi di kelas oleh anggota staf (lembaga yang berkaitan dengan rokok), dan bisa melalui kegitan kesehatan disekolah maupun pada masyarakat. Menurut Wardana (2012), penilaian siswa tentang pelajaran pendidikan jasmani akan mempengaruhi proses belajar siswa, yaitu dalam belajar yang positif. Apabila siswa memiliki penilaian yang positif atau baik terhadap mata pelajaran tersebut, maka ia akan memiliki motivasi belajar yang baik atau positif, dengan demikian proses belajar juga akan baik, begitu juga sebaliknya. Jika hal ini disesuaikan dengan penelitian mengenai penilaian terhadap PHW, maka terdapatnya mata pelajaran mengenai dampak dari rokok memungkinkan menimbulkan penilaian tersendiri mengenai PHW atau dampak dari rokok tersebut. Dalam penelitian ini, tidak ada hubungan antara kegiatan sekolah (salah satu kegiatan tersebut adalah terdapat mata pelajaran menganai rokok dan dampaknya) dengan penilaian mengenai PHW pada pelajar SMP di Kota Yogyakarta.

\section{Pengetahuan tentang Dmpak Kesehatan}

\section{Akibat Rokok}

Pengetahuan tentang rokok menunjukkan kemaknaan, dimana $\rho$ value 0,024 $(\rho<0,05)$ dengan OR/Exp (B) 2.041. Hal ini berarti bahwa pengetahuan tentang rokok yang baik ini mempunyai peluang 2 kali mendukung untuk terjadinya penilaian 
positif PHW dibandingkan pengetahuan tentang rokok yang kurang baik.

Hal ini sesuai dengan penelitian dari Hidayat (2012), bahwa pengetahuan bahaya merokok berhubungan dengan perilaku merokok. Menurut Rachmat, Thaha, dan Syafar, bahwa pengetahuan merupakan faktor predisposing yang mempengaruhi perilaku seseorang, mereka yang berpengetahuan tinggi diharapkan berperilaku positif. Pengetahuan dalam penelitian ini adalah baik, hal ini sejalan dengan penelitian Rachmat $d k k$ (2013), yaitu pengetahuan mereka tentang rokok berada pada kategori tinggi $(83,4 \%)$.Penelitian yang dilakukan oleh Kenkel dalam Chotidjah (2012), menunjukkan bahwa di antara perilaku mengkonsumsi alkohol, merokok dan olahraga maka perilaku merokoklah yang memiliki hubungan yang paling erat dengan pengetahuan tentang kesehatan. Hal ini berarti bahwa perilaku merokok dapat dengan mudah berubah jika pengetahuan tentang rokok dan dampaknya pada kesehatan meningkat. Chotidjah juga menjelaskan bahwa orang yang memiliki pengetahuan yang benar tentang rokok dan konsekuensinya akan cenderung memiliki pusat kendali kesehatan internal dan tidak merokok. Sebaliknya, seseorang yang memiliki sedikit pengetahuan tentang rokok maka ia cenderung memiliki pusat kendali kesehatan eksternal dan merokok.
Pengetahuan tentang rokok dalam penelitian ini berhubungan dengan penilaian pelajar SMP di Kota Yogyakarta terhadap PHW. Berdasarkan hasil penelitian diketahui bahwa sebesar $83,4 \%$ responden memiliki pengetahuan tentang rokok yang baik. Salah satu poin pertanyaan pengetahuan tersebut adalah merokok dapat mengakibatkan kanker paru dan mulut. Poin ini sama dengan salah satu PHW. Poin ini mendapat jawaban benar sebesar 97,5\%, ini menandakan bahwa responden cukup mengetahui dampak negatif dari rokok. Kanker merupakan salah satu penyakit yang timbul akibat merokok.

Selain hasil kuantitatif, pengetahuan tentang rokok juga didapat dari indepth interview. Kesimpulan dari pengetahuan tentang rokok adalah informan pelajar yang tidak merokok dan mantan perokok mengetahui setidaknya satu penyakit akibat rokok, namun hanya satu orang subjek yang menjawab benar mengenai sakit akibat rokok. Hanya sedikit informan pelajar yang tidak mengetahui kandungan bahaya rokok. Sisanya mengetahui bahwa nikotin merupakan salah satu kandungan berbahaya pada rokok.

Menurut Department of Health and Human Services (2010), "merokok dapat menyebabkan kanker pada hampir seluruh tubuhmu". Penyakit kanker yang mereka maksud adalah kanker mulut, hidung, dan kerongkongan, kanker laring (pita suara), 
kanker trachea (batang tenggorokan), kanker esophagus, kanker paru-paru, kanker perut, kanker pankreas, kanker ginjal dan saluran kemih, kanker kandung kemih, kanker serviks, dan kanker tulang sumsum serta darah.

Kandungan rokok yang paling banyak diketahui oleh responden adalah nikotin. Komponen ini paling banyak dijumpai di dalam rokok. Jangka panjang, nikotin akan menekan kemampuan otak untuk mengalami kenikmatan, sehingga perokok akan selalu membutuhkan kadar nikotin yang semakin tinggi untuk mencapai tingkat kepuasan dan ketagihannya. Sifat nikotin yang adiktif ini dibuktikan dengan adanya jurang antara jumlah perokok yang ingin berhenti merokok dan jumlah yang berhasil berhenti. ${ }^{34}$

Hasil uji statistik diperoleh nilai $\rho$ sebesar 0,010, artinya ada hubungan antara pengetahuan tentang rokok dengan penilaian pelajar SMP di Kota Yogyakarta terhadap PHW. Hasil penelitian ini sesuai dengan penelitian Trirahayu (2009), bahwa penilaian remaja perokok tentang dampak merokok bagi kesehatan sangat dipengaruhi oleh pengetahuan, sumber informasi yang dimiliki oleh remaja dan fenomena yang ada di sekitarnya.

\section{Self Estem (Harga Diri)}

Sebanyak 51,9\% reseponden yang memiliki harga diri tinggi. Hasil uji statistik diperoleh nilai $\rho$ sebesar 0,575 , artinya ada tidak hubungan antara self esteem dengan penilaian pelajar SMP di Kota Yogyakarta terhadap PHW.

Harga diri adalah salah satu yang sangat menentukan perilaku seseorang. Individu senantiasa akan berusaha untuk berperilaku sesuai dengan standar yang diterapkan dirinya atau ideal diri. Keberhasilan individu mencapai perilaku sesuai dengan standar tersebut, maka individu akan menilai dirinya tinggi atau mempunyai harga diri tinggi, begitu juga sebaliknya. Terpenuhinya harga diri akan menimbulkan sikap yang positif bagi dirinya. Individu akan semakin percaya diri dan optimis dalam beraktivitas sehari-hari (Suwarno, 2009).

Menurut Appau (2011), harga diri memiliki pengaruh yang kuat pada penyesuaian pada banyak aspek kehidupan remaja. Harga diri diketahui mempengaruhi prestasi pendidikan, hubungan sosial, kesehatan mental dan kemampuan untuk mengatasi stres. Menurut Price dalam penelitian Appau (2011), remaja dengan self estem rendah ini dianggap kurang mampu untuk menolak undangan untuk menggunakan zat atau obat, termasuk rokok.

Menurut Rahmania dan Ika (2012), apabila remaja putri memiliki self esteem tinggi, maka mereka mengembangkan body image positif yang berarti mereka memiliki 
penilaian positif mengenai diri mereka. rangkaian peristiwa yang pernah kita Pendapat Goodall (2005), bahwa hadapi. Menurut Walgito (2010), jika karakteristik dan situasi kehidupan individu mengalami banyak pengalaman berpengaruh terhadap penilaian terhadap yang menyenangkan dengan rokok, maka rasa takut. Dan untuk contoh adalah self kemungkinan besar individu tersebut akan esteem ini tidak berhubungan dalam merokok.

penilaian dalam pengungkapan rasa takut.

\section{Pengalaman Merokok}

Hasil dari penelitian ini adalah sebanyak $54,6 \%$ responden yang termasuk dalam kategori kurang berpengalaman terhadap perilaku merokok. Selain data kuantitatif, pengalaman merokok juga didapat dari wawancara mendalam kepada informan. Kesimpulan dari pengalaman informan pelajar mengenai rokok adalah tiga dari informan tidak merokok, namun dilingkungan mereka terdapat perokok aktif atau mantan perokok. Sebanyak tiga informan merupakan mantan perokok. Dan sebanyak empat informan sisanya adalah perokok aktif. Mereka memulai perilaku merokoknya sedari SD, namun aktif untuk terus merokok dari awal SMP.

Hasil uji statistik diperoleh nilai $\rho$ sebesar 1,000, artinya ada tidak hubungan antara pengalaman merokok dengan penilaian pelajar SMP di Kota Yogyakarta terhadap PHW. Menurut Jalaludin Rakhmat (2009), pengalaman mempengaruhi kecermatan penilaian. Pengalaman tidak selalu lewat proses belajar formal. Pengalaman kita bertambah juga melalui Poin pengalaman ini lebih kearah kejujuran dari responden dalam menjawab hal yang berkaitan dengan pernah mencoba merokok dan perilaku merokoknya. Selama penelitian berlangsung, peneliti tidak menemukan pelajar yang merokok. Peneliti berkerja sama dengan guru pendamping dalam mencari pelajar yang pernah ketahuan merokok, dan atau diketahui pernah merokok. Peneliti mendapat data nama pelajar yang pernah ketahuan merokok. Namun setelah di singkronkan dengan pengisian kuesioner, hasilnya adalah pelajar tersebut tidak mengakui bahwa dia pernah mencoba merokok atau masih merokok. Hal ini dimungkinkan terjadi untuk beberapa responden yang tidak peneliti dapatkan data dari sekolah atau guru pendamping.

Hal ini sama dengan penelitian dari Chotidjah (2012), hasil dari penelitiannya adalah tes pengetahuan tentang rokok juga kurang reliabel, kondisi ini disebabkan oleh kekhawatiran subjek jika mereka memberikan jawaban yang sebenarnya dan diketahui oleh pihak sekolah maka akan mendapatkan sangsi walaupun mereka telah diberikan jaminan bahwa data penelitian ini 
akan dijamin kerahasiaannya. Afrinanda (2014) berpendapat bahwa pengalaman anak dalam kelompoknya mempengaruhi bagaimana seharusnya bersikap dan mempersepsikan (menilai) dirinya dan lingkungannya.

\section{Faktor Lingkungan}

Hasil penelitian ini menunjukkan bahwa sebesar $51,9 \%$ merupakan lingkungan perokok, seperti dari orang tua, saudara, dan teman. Hanya $11,2 \%$ yang orang tuanya selalu merokok, dan hanya $4,0 \%$ yang temannya pernah mengajak merokok. Berdasarkan hasil uji statistik diperoleh nilai $\rho$ sebesar 0,174 , artinya tidak ada hubungan antara faktor lingkungan dengan penilaian pelajar SMP di Kota Yogyakarta terhadap PHW.

Menurut Appau (2011) yang mengambil dari penelitian Alexander $d k k$, adalah jika didalam lingkungan remaja tersebut terdapat orang tua dan atau anggota keluarga lain yang menggunakan tembakau, maka rasa ingin tahu remaja tersebut muncul. Rasa ingin tahu ini bisa hanya sekedar dalam pikirannya, dan atau juga dengan tindakan, yaitu mencoba merokok. Menurut Logan dan Carlini-Marlatt (2005), orang tua memiliki banyak pengaruh atas sikap dan keyakinan anak-anak mereka tentang merokok, terutama melalui tahap inisiasi. Sangat penting untuk mengajarkan orang tua bagaimana berkomunikasi dengan anak-anak mereka tentang penggunaan tembakau. Satu studi melaporkan menurunkan kerentanan anak-anak untuk merokok melalui pendidikan orang tua, meningkatkan keterampilan dan kenyamanan tingkat orang dewasa dalam membahas masalah ini dengan anak-anak mereka. Meskipun anak-anak mungkin memiliki tingkat onset jauh lebih tinggi jika kedua orang tua mereka merokok (25\%) dibandingkan dengan dua orang tua merokok (5\%), sosialisasi anti-merokok mengurangi resiko awal merokok, bahkan jika kedua orang tua mereka adalah perokok.

\section{Partisipasi dalam Kegiatan Kesehatan di} Sekolah

Hasil penelitian ini menunjukkan sebanyak $80,1 \%$ responden berpartisipasi dalam ektrakulikuler kesehatan, keikutsertaan dalam kunjungan kesehatan, dan perayaan kesehatan. Hasil uji statistik diperoleh nilai $\rho$ sebesar 0,584 , artinya tidak ada hubungan antara partisipasi dalam kegiatan kesehatan di sekolah dengan penilaian pelajar SMP di Kota Yogyakarta terhadap PHW. Penelitian Imelda, Juanita, dan Rusmalawaty (2012), yang menyatakan bahwa $94,4 \%$ tingkat partisipasi dalam penerapan kawasan tanpa rokok yang tertinggi pada partisipasi aktif. Hal yang sama datang dari penelitian Fatmasari, Indar, dan Darmansyah (2014), 
yang menyatakan bahwa kurang dari setengah responden perokok yang akan ikut berperan dalam penanggulangan masalah rokok seperti program anti tembakau. Hal ini menunjukkan bahwa keikutsertaan pelajar SMP di Kota Yogyakarta juga bisa memberi kontribusi terhadap keberlangsungan program pemerintah yang berhubungan dengan rokok, salah satunya adalah program PHW ini.

\section{Paparan Penyuluhan Kesehatan}

Sebanyak $68,0 \%$ dalam penelitian ini responden mendapatkan paparan penyuluhan kesehatan. Hasil uji statistik diperoleh nilai $\rho$ sebesar 0,651 , artinya ada tidak hubungan antara paparan penyuluhan dengan penilaian pelajar SMP di Kota Yogyakarta terhadap PHW. Hasil analisis univariat menunjukkan bahwa sebesar $68 \%$ responden masuk kedalam kategori pernah terpapar penyuluhan ini dikarenakan sebagian besar responden pernah mendapatkan penyuluhan tentang kesehatan umum di Sekolah, pernah mendapatkan penyuluhan tentang dampak rokok di Sekolah, pernah mendapat informasi mengenai dampak rokok dari buku cetak, pernah mendapat informasi mengenai dampak rokok dari majalah atau koran, dan pernah mendapat informasi mengenai dampak rokok dari media sosial. Sekarang ini paparan penyuluhan tidak hanya diberikan langsung oleh pihak kesehatan, melaikan melaui sarana prasarana media cetak maupun media sosial.

Menurut CDC (2004), target pemasaran program atau pemasaran informasi bisa menggunakan berbagai macam media, misalnya situs web, video, brosur, koran atau majalah, poster, dan pengumungan sekolah. Menurut penelitian dari Kao, Yen (1997) dan Lee (1999) dalam Tsai, dkk (2005), bahwa penyuluhan sebagai program pencegahan tembakau ini memiliki pengaruh positif pada penggunaan tembakau pada pelajar. Penelitian Tsai $d k k$ (2005)juga mengahsilkan bahwa pelaksanaan penyuluhan cukup berpengaruh pada pengetahuan pelajartentang bahaya dari tembakau dan sikap terhadap anti merokok.

\section{SIMPULAN}

Hampir setengah dari responden memiliki penilaian negatif terhadap PHW, yang artinya adalah tidak menimbulkan rasa ngeri, tidak serem, tidak takut, tidak jijik, dan berpikir bahwa perokok aktif tidak akan terkena hal yang ada pada gambar peringatan, serta memiliki penilaian bahwa karakteristik media yang kurang baik. Gambar yang paling banyak mendapatkan pilihan "ngeri, serem, dan takut" adalah gambar 5 (Merokok sebabkan Kanker ParuParu dan Bronkitis Kronis). Gambar yang paling banyak mendapatkan pilihan "jijik" adalah gambar 5 (Merokok sebabkan 
Kanker Paru-Paru dan Bronkitis Kronis). Gambar yang paling banyak mendapatkan pilihan "perokok aktif akan terkena hal yang ada pada gambar" adalah gambar 1 (Merokok sebabkan Kanker Mulut). Informan menyatakan bahwa PHW bisa membuat seseorang yang belum merokok untuk berniat tidak merokok. PHW juga mampu membuat mantan perokok untuk berniat berhenti merokok atau tidak mau melanjutkan perilaku merokoknya setelah melihat PHW tersebut, khususnya untuk gambar 1 (Merokok sebabkan Kanker Mulut), 3 (Merokok Sebabkan Kanker Tenggorokan), dan 5 (Merokok sebabkan Kanker Paru-Paru dan Bronkitis Kronis). Namun PHW tidak membuat seorang perokok aktif untuk berhenti merokok.

\section{KEPUSTAKAAN}

Afrinanda, Y. 2014. Self-Esteem pada Wanita Usia Dewasa Awal yang Berkerja Sebagai Waiters di Bar.

Appau, I. K. 2011.Smoking Habits Among Adolescents (Tesis).

Badan Penelitian dan Pengembangan Kesehatan. 2013. Riset Kesehatan Dasar 2013. Kementrian Kesehatan Republik Indonesia.

Blow, L., Leicester, A., Windmeijer, F. 2005. Parental Income and Children;s Smoking Behaviour : Evidence from tnge British Household Panel Survey.

CDC. 2004. Youth Tobacco Cessation - A Guide for Making Informed Decisions.
Chotidjah, S. 2012. Pengetahuan tentang Rokok, Pusat Kendali Kesehatan Eksternal dan Perilaku Merokok. Makara, Sosial Humaniora, Volume 16, Nomor 1, halaman 49-56.

Department of Health and Human Services. 2010. A Report of the Surgeon General: How Tobacco Smoke Causes Disease: What It Means to You.

Edoka, I. P. 2013. Essays on Parents' Socioeconimic Status, Child Health Outcomes and Smoking Behaviours.

Fawzani, N., dan Triratnawati, A. 2005. Terapi Berhenti Merokok (Studi Kasus 3 Perokok Berat). Makara, Kesehatan, Volume 9, Nomor 1, Halaman 15-22.

Goodall, C. E. 2005. Modifying Smoking Behavior Through Public Service Announcements And Cigarette Package Warning Labels: A Comparison Of Canada And The United States.

Haris, A., dan Mukhtar I. R. R.. 2012. Asap Rokok sebagai Bahan Pencemar dalam Ruangan. CDK-189. Vol. 39, No. 1.

Hidayat, T.. 2012. Analisis Faktor yang berhubungan dengan Perilaku Merokok pada Mahasiswa Keperawatan di Wilayah provinsi Kalimantan Selatan (Tesis).

Kementrian Kesehatan Republik Indonesia. 2013. Peraturan Mentri Kesehatan Republik Indonesia No. 40, tentang "Peta Jalan Pengendalian Dampak Konsumsi Rokok bagi Kesehatan".

Khuloud, J. M. K. D. 2007. Assessment of Health Behavior among Palestinian Adolescent School Children in the West Bank and Gaza Strip: The Case of Tobacco Smoking (Tesis). 
Logan, D., dan Carlini-Marlatt, B. 2004. Smoking and Adolescence: Some Issues on Prevention and Cessation.

Pemerintah RI. 2012. Peraturan Pemerintah Republik Indonesia No 109 tahun 2012 tentang "Pengamanan Bahan yang Mengandung Zat Adiktif berupa Produk Tembakau bagi Kesehatan".

Rachmat, M., Thata, R. M., dan Syafar, M.. 2013.Perilaku Merokok Remaja Sekolah Menengah Pertama. Kesmas, Jurnal Kesehatan Masyarakat Nasional. Volume 7, Nomor 11.

Rahmania P. N., Ika, Y. C.. 2012. Hubungan antara Self Esteem dengan Kecenderungan Body Dysmorphic Disorder pada Remaja Putri. Jurnal Psikologi Klinis dan Kesehatan Mental, Volume 1, Nomor 2.

Rakhmat, J. 2009. Psikologi Komunikasi. Pt. Remaja Rosdakarya, Bandung.

Sentra Informasi Keracunan Nasional. 2014. Remaja, Tembakau dan Rokok. Pusat Informasi Obat dan Makanan, Badan POM.

Sheaves, R. A.. 2008. The Effectiveness of Tobacco Prevention \& Cessation Programs: A Focused-Analysis of the Virginia Tobacco Settlement Foundation Programs (Disertasi).

Suwarno, W. 2009. Psikologi Perpustakaan. Sagung Seto, Jakarta.

Trirahayu, K., E. 2009. Persepsi remaja perokok tentang dampak merokok terhadap kesehatan.

Tsai, W., Kung, P., Hu, H., Ho, C., Lin, D., Hsieh, C., Teng, Y., Chen, C., Wu, J., dan Chiang, C. 2005. Effects of $a$ Tobacco Prevention Education Program on Adolescents' Knowledge of and Attitudes Toward Smoking.
Walgito, B. 2010. Pengantar Psikologi Umum. Andi Offset, Yogyakarta.

Wardana, A. 2012. Persepsi Siswa Kelas XI SMA N 1 Depok Sleman terhadap Kegiatan Belajar Mengajar Pendidikan Jasmani Tahun 2010/2011.

Word Health Organization (WHO) Indonesia. 2009. Label Peringatan Kesehatan pada Kemasan Produk Tembakau. 